\title{
Fed Batch Enzymatic Saccharification of Food Waste Improves the Sugar Concentration in the Hydrolysates and Eventually the Ethanol Fermentation by Saccharomyces cerevisiae $\mathbf{H 0 5 8}$
}

\author{
Shoubao Yan ${ }^{1,2 *}$, Jianming $\mathrm{Yao}^{2}$, Liming $\mathrm{Yao}^{2}$, Zhijun $\mathrm{Zhi}^{2}$, Xiangsong $\mathrm{Chen}^{2}$ and \\ Jingyong $\mathbf{W} \mathbf{u}^{2}$ \\ ${ }^{1}$ School of Life Science; Huainan Normal University; Huainan, Anhui 232001; China. ${ }^{2}$ Key Laboratory of Ion Beam \\ Bio-engineering of Institute of Plasma Physics; Chinese Academy of Sciences; Hefei 230031; China
}

\begin{abstract}
The enzymatic hydrolysis of food waste by commercially available enzymes and the subsequent ethanol fermentation of the hydrolysates by Saccharomyces cerecisiae H058 were studied in this work. The optimum batch enzymatic conditions were found to be saccharification $\mathrm{pH}$ of 4.5 , temperature of $55^{\circ} \mathrm{C}$, glucoamylase concentration of 120 $u / g, \alpha$-amylase concentration of $10 \mathrm{u} / \mathrm{g}$, solid-liquid ratio of $1: 0.75(w / w)$. Fed batch hydrolysis process was started with a solid-liquid ratio of $1: 1(w / w)$, with solid food waste added at time lapse of $2 \mathrm{~h}$ to get a final solid-liquid ratio of 1: $0.5(w / w)$. After 4 h of reaction, the reducing sugar concentration reached $194.43 \mathrm{~g} / \mathrm{L}$ with a enzymatic digestibility of $93.12 \%$. Further fermentation of the batch and fed batch enzymatic hydrolysates, which contained reducing sugar concentration of 131.41 and $194.43 \mathrm{~g} / \mathrm{L}$ respectively, was performed using Saccharomyces cerevisiae H058, 62.93 and $90.72 \mathrm{~g} / \mathrm{L}$ ethanol was obtained within $48 \mathrm{~h}$.
\end{abstract}

Key words: Food waste, Enzymatic hydrolysis, Hydrolysates, Fermentation, Ethanol production

\section{INTRODUCTION}

The global demand for ethanol has been increasing in recent years because of its wide use in chemical and motor-fuel industries, and its important role in reduction of green house gas emissions. Ethanol has been produced mainly from corn in America and China and from sugarcane in Brazil. However, since corn is a major food source, its use as a fuel raw material has been criticized as it has led to a dramatic increase in the price of corn. Since 2006 the Chinese government has restricted the use of corn for ethanol production. Therefore, waste biomass such as corn stover, waste wood and waste food are much more attractive than corn as cheap raw material for ethanol production.

Food waste is a kind of organic solid waste discharged from restaurants, cafeterias, households, and accounts for a considerable proportion of municipal solid waste in China (Wang et al. 2005). For example, over 1300 tonnes of food waste was generated per day in Shanghai, and over 1000 tonnes in Beijing. Landfill was once the primary choice for handling these wastes but has now been banned because of the exhaustion of existing landfill sites, moreover, it is difficult to find new sites and the leachate generated by these

*Author for correspondence: yhj_ysb@sohu.com 
materials requires secondary wastewater treatments (Cho et al. 1995). The incineration of food waste is unsuitable because of its high water content and the possibility of dioxin generation (Choi et al. 2003). The major conventional recycling method for food waste has been to employ it as animal feed and fertilizer, which has been practiced as ways of treating large amounts of the food wastes. However, large amounts of wastewater are generated when desalting the food wastes for fertilizer production, and animal feeds produced from this material often creates hygiene problems for feeding animals (Moon et al.2009). Therefore, it is imperative to overcome the technological and systematic dilemma of the conventional recycling method for food waste and simultaneously develop an environment friendly recycling method that can convert food waste to a high value product such as fuel ethanol.

An efficient conversion of food waste to ethanol depends mainly on the extent of carbohydrate saccharification. It is well known that high extent of saccharification efficiency requires low substrate concentration in the batch operation system, however, low substrate concentration would yield low concentrations of sugars for fermentation and ethanol for distillation so that ethanol recovery cost would increase (Zheng et al. 2009). Also, low substrate concentration would increase both the capital cost of equipment and the operation costs in order to reach a certain ethanol production capacity. Therefore, high substrate concentration is more preferable and economically practical than low substrate concentration. However, the problems of sugar inhibitions and mixing with high substrate concentration need to be solved properly.

In fed batch hydrolysis, solid food waste and/or enzymes are added into reactors stepwise and solid food waste are gradually degraded; therefore, the mixture becomes more fluid and more solid food waste could be added (Rudolf et al. 2005). As a result, fed batch is expected to be a better procedure than batch on dealing with the situation of high substrate concentration and low enzyme concentration. Additionally, fed batch can generate high reducing sugar concentration for fermentation and finally yield high ethanol concentration for distillation resulting in significantly decrease of ethanol production cost (Ballesteros et al. 2009). In the present study, the optimization of enzymatic saccharification using both $\alpha$-amylase and glucoamylase was carried out to improve the hydrolysis of the food waste. In order to increase the sugar concentration in enzymatic hydrolysates, the fed batch enzymatic hydrolysis of chopped food waste was carried out. Thereafter, the ethanol fermentation of batch enzymatic hydrolysates and fed batch enzymatic hydrolysates by Sacch. cerevisiae $\mathrm{H} 058$ were investigated in this paper.

\section{MATERIALS AND METHODS}

\section{Microorganism and culture conditions}

Sacch. cerevisiae H058 used in this study was obtained from Key Laboratory of Ion Beam Bioengineering of Institute of Plasma Physics, Chinese Academy of Sciences. It was maintained on slants of the agar medium (w/v): glucose $2 \%$, peptone $1 \%$, yeast extract $0.5 \%$ and agar $2 \%$, and kept at $4^{\circ} \mathrm{C}$. The seed was grown in 5\% YPD (5\% glucose, $1 \%$ yeast extract, $2 \%$ peptone) medium. Pre-cultivation was performed aerobically at $30^{\circ} \mathrm{C}$ for $24 \mathrm{~h}$ with mixing at $150 \mathrm{rpm}$ using a rotary shaker, then the resulting pre-cultivation broth was used as inoculum.

\section{Enzymes}

Commercial enzyme solutions, fungal $\alpha$-amylase and glucoamylase purchased from Shandong Longda Bio-Products Company Limited (China), were used for food waste saccharification. According to the information sheet, the optimum temperature for fungal $\alpha$-amylase is in the range of 50-60 and for glucoamylase is in the range of 5560 . Regarding optimum $\mathrm{pH}$, the range for fungal $\alpha$-amylase is from 4.0 to 6.5 and for glucoamylase is from 4.0 to 4.5 . The activity of fungal $\alpha$-amylase and glucoamylase is $5000 \mathrm{u} / \mathrm{mL}$ and 150000 $\mathrm{u} / \mathrm{mL}$, respectively. One fungal $\alpha$-amylase unit is defined as the amount of enzyme that hydrolyzes 1 mg water soluble corn starch per minute under the assay conditions. One glucoamylase unit is defined as the amount of enzyme required to produce $1 \mathrm{mg}$ of glucose in 1 hour under the assay conditions.

\section{Food waste}

Food waste used in this study was collected from the dining room located in Institute of Plasma Physics, Chinese Academy of Sciences. After separating out bones and shells, the remaining waste was mixed with water at a ratio of 1: 1 (w/w) and chopped into small pieces using a fruit mixer. 


\section{Batch enzymatic hydrolysis}

Effect of glucoamylase concentration on the enzymatic hydrolysis of food waste

Enzymatic hydrolysis experiments were conducted in $500 \mathrm{~mL}$ Erlenmeyer flasks each containing 200 $\mathrm{g}$ minced food waste mixture (The solid-liquid ratio was kept at a constant of 1: $1(\mathrm{w} / \mathrm{w}))$, in a shaking incubator. Various glucoamylase concentrations, including 80, 100, 120, and 140 $\mathrm{u} / \mathrm{g}$ food waste were tested in this section. The $\alpha$ amylase concentration of $8 \mathrm{u} / \mathrm{g}$ food waste remained constant under all different glucoamylase concentrations. The enzymatic hydrolysis was performed at $\mathrm{pH} 5.0,50^{\circ} \mathrm{C}$, and 150 rpm for $4 \mathrm{~h}$. Samples were withdrawn at the start and after $0.5,1,1.5,2,2.5,3,3.5$, and $4 \mathrm{~h}$ of enzymatic hydrolysis.

Effect of $\alpha$-amylase concentration on the enzymatic hydrolysis of food waste

In order to study the effect of $\alpha$-amylase concentration on the enzymatic hydrolysis of food waste, four $\alpha$-amylase concentrations of $6,8,10$, and $12 \mathrm{u} / \mathrm{g}$ food waste were tested with glucoamylase concentration fixed at $120 \mathrm{u} / \mathrm{g}$ food waste. Other conditions were the same as Section 2.4.1.

Effect of temperature on the enzymatic hydrolysis of food waste

The effect of temperature on the enzymatic hydrolysis of food waste was carried out at various temperatures of $50,55,60$, and $65^{\circ} \mathrm{C}$. Two kinds of enzymes, $\alpha$-amylase and glucoamylase were added to each flask with the amount of $10 \mathrm{u} / \mathrm{g}$ and $120 \mathrm{u} / \mathrm{g}$ food waste, respectively. Other conditions were the same as Section 2.4.1.

Effect of $\mathrm{pH}$ on the enzymatic hydrolysis of food waste

The effect of initial $\mathrm{pH}$ was studied by conducting enzymatic hydrolysis at various initial $\mathrm{pH}$ of 4.0, $4.5,5.0$, and 5.5 with $3 \mathrm{M}$ sodium hydroxide. Two kinds of enzymes, $\alpha$-amylase and glucoamylase were then added to each flask with the amount of $10 \mathrm{u} / \mathrm{g}$ and $120 \mathrm{u} / \mathrm{g}$ food waste, respectively. These flasks were incubated at $55^{\circ} \mathrm{C}$ for $4 \mathrm{~h}$. Other conditions were the same as Section 2.4.1.
Effect of solid-liquid ratio on the enzymatic hydrolysis of food waste

Five different solid-liquid ratio of 1: 0.5, 1: 0.75, 1: 1, 1: 1.25, and 1: $1.5(\mathrm{w} / \mathrm{w})$ were investigated in the batch enzymatic hydrolysis step. In all experiments, two kinds of enzymes, $\alpha$-amylase and glucoamylase were added to each flask with the amount of $10 \mathrm{u} / \mathrm{g}$ food waste and $120 \mathrm{u} / \mathrm{g}$ food waste, respectively. The enzymatic hydrolysis was performed at $\mathrm{pH} 4.5,55^{\circ} \mathrm{C}$, and $150 \mathrm{rpm}$ for $4 \mathrm{~h}$. Other conditions were the same as Section 2.4.1.

\section{Fed batch enzymatic hydrolysis}

Fed batch enzymatic saccharification of food waste was carried out at optimized conditions of saccharification with initial solid-liquid ratio of 1 : 1 , and enzyme loadings of $10 \mathrm{u} \alpha$-amylase/g food waste and $120 \mathrm{u}$ glucoamylase/g food waste. After the initial batch phase, pretreated food waste, which had been $\mathrm{pH}$-adjusted to 4.5 with $3 \mathrm{~N} \mathrm{NaOH}$ and $3 \mathrm{~N} \mathrm{HCl}$, was added at 2 hour to get a final solid-liquid ratio of 1: 0.5 , simultaneously adding certain amount of $\alpha$-amylase (10 u/g fed food waste) and glucoamylase (120 u/g fed food waste). Samples were withdrawn at the start and after 0.5 , $1,1.5,2,2.5,3,3.5,4,4.5$, and 5.0 of enzymatic hydrolysis. The total hydrolysis time was set $5 \mathrm{~h}$. Other enzymatic hydrolysis conditions were the same as Section 2.3.

\section{Ethanol fermentation of enzymatic hydrolysate}

After enzymatic hydrolysis, the food waste hydrolysate was centrifugated at $8000 \mathrm{rpm}$ for 10 min and the supernatant was separated and used for ethanol production. The supernatants of batch and fed batch enzymatic hydrolysates containing $131.41 \mathrm{~g} / \mathrm{L}$ and $194.43 \mathrm{~g} / \mathrm{L}$ sugars, respectively, and each supplemented with $8 \mathrm{~g} / \mathrm{L}$ YEP (3 g yeast extract and $5 \mathrm{~g}$ peptone) and used as ethanol fermentation medium. After adjusting $\mathrm{pH}$ values to 5.0 with $3 \mathrm{~N} \mathrm{NaOH}$ and $3 \mathrm{~N} \mathrm{HCl}$, the ethanol production medium was autoclaved at $110^{\circ} \mathrm{C}$ for $15 \mathrm{~min}$ and then used for batch ethanol fermentation. Sacch. cerevisiae H058 suspension $\left(2 \% \mathrm{v} / \mathrm{v}\right.$, approximately $\left.1 \times 10^{8} \mathrm{CFU} / \mathrm{mL}\right)$ was inoculated in $400 \mathrm{~mL}$ ethanol production medium in a $500 \mathrm{~mL}$ Erlenmeyer flask with a rubber stopper, it was incubated at $30^{\circ} \mathrm{C}$ with mild agitation $(100 \mathrm{rpm})$ for a period up to $60 \mathrm{~h}$. Samples were withdrawn at regular intervals of 12 $\mathrm{h}$ and centrifuged at $8000 \mathrm{rpm}$ for $10 \mathrm{~min}$ at $4^{\circ} \mathrm{C}$. 
The cell free supernatant was used for the determination of ethanol and sugar.

\section{Analytical methods}

Total solid (TS), volatile total solid (VTS), $\mathrm{pH}$ were analyzed in accordance to Standard Methods (APHA, 1995). The moisture content in the food waste was determined by the standard drying method in an oven at $105^{\circ} \mathrm{C}$ to constant mass. The ash content was determined by slow combustion of the sample at $650^{\circ} \mathrm{C}$ for $0.5 \mathrm{~h}$ (Chinese National Standard GB/T 5009.4, 2003). The total sugar concentration in the food waste was assayed by the Somogyi-Nelson method (Somogyi 1952). Cellulose content in samples was determined by performing a two-step hydrolysis (Chinese National Standard GB/T 5009.10, 2003). The protein content of food waste was estimated by determining the total nitrogen content using the Kjeldahl method and multiplying by the conversion factor of 6.25 (APHA 1995). Lipid concentration was determined according to the Soxhlet method (Nielsen 2002). Samples obtained from enzymatic hydrolysis and ethanol fermentation were centrifuged at $8000 \mathrm{rpm}$ for 5 min and the supernatant was filtered through a chromato-disc filter (pore size: $0.45 \mu \mathrm{m}$ ). The reducing sugar was determined using the 3,5dinitrosalicylic acid (DNS) method (Miller 1959). The ethanol concentration was measured by using Shimadzu GC-2050 gas chromatography with cbp20 capillary column and a flame ionization detector. The chromatogram was run at $180^{\circ} \mathrm{C}$ oven temperature and $90^{\circ} \mathrm{C}$ injection temperature using $\mathrm{N}_{2}$ as a carrier gas and $\mathrm{H}_{2}$ as a flaming gas (Yu et al. 2009).

The ethanol yield $\left(\mathrm{Y}_{\mathrm{p} / \mathrm{x}}\right)$ was calculated as the actual ethanol produced and expressed as $g$ ethanol per $g$ total sugar utilized. The volumetric rate of ethanol production $(\mathrm{g} / \mathrm{L} / \mathrm{h})$ was calculated by ethanol concentration produced $(\mathrm{g} / \mathrm{L})$ divided by fermentation time (h). The enzymatic digestibility index was calculated by as follows:

Enzymatic digestibility index $=$ (reducing sugar obtained /starch content in the substrate).

\section{RESULTS AND DISCUSSION}

\section{Characteristics of the food waste mixture}

The characteristics of the food waste mixture used

in this study are presented in Table 1 . The $\mathrm{pH}$ of the food waste mixture was very low (4.46), owing to a considerable amount of acidified food residues and the generation of volatile fatty acids during storage. The dry mass of food waste was mainly composed of starch sugars, protein, fat and cellulose, which could be regarded as a suitable substrate for ethanol production. These characteristics were very similar to others that have been reported (Sakai et al. 2000; Shin et al. 2004; Tang et al. 2008).

\section{Batch enzymatic hydrolysis}

Effect of glucoamylase concentration on the enzymatic hydrolysis of food waste

Figure 1a shows the enzymatic digestibility index has increased from 0.73 to 0.78 after $2.5 \mathrm{~h}$ of enzymatic hydrolysis with the increase of glucoamylase concentration from 80 to $100 \mathrm{u} / \mathrm{g}$ food waste, and 0.1 increase of digestibility index was found when glucoamylase concentration increased further to $120 \mathrm{u} / \mathrm{g}$ food waste. However, no significant improvement of enzymatic digestibility was achieved when glucoamylase concentration ranged from 120 to $140 \mathrm{u} / \mathrm{g}$ food waste.

Figure $1 \mathrm{~b}$ also shows the concentration of reducing sugar extracted from the food waste broth hydrolyzed by various units of glucoamylase, and constant unit of $\alpha$-amylase ( $8 \mathrm{u} / \mathrm{g}$ food waste), after $4 \mathrm{~h}$ incubation. In the control treatments, in which no enzyme was added, the amount of reducing sugar increased to approximately 5.68 $\mathrm{g} / \mathrm{L}$ after $4 \mathrm{~h}$. This might due to the partial hydrolysis by naturally existing microorganisms on the organic material of the food waste. A considerable amount of initial reducing sugar concentration (approximately $7.48 \mathrm{~g} / \mathrm{L}$ ) was detected in the control. This indicates that food waste itself contains a significant amount of water soluble sugar, which is extracted from the minced food waste, as given in Table 1 . In the case of glucoamylase treaments, the sugars release increased with increase in enzyme dosage up to $120 \mathrm{u} / \mathrm{g}$ food waste, which resulted in $80.74 \mathrm{~g} / \mathrm{L}$ of reducing sugar after $2.5 \mathrm{~h}$ of incubation. An increase in the enzyme dosage beyond $120 \mathrm{u} / \mathrm{g}$ did not cause any further improvement in the saccharification (Fig. 1b). Therefore, the optimal enzyme dosage was identified as $120 \mathrm{u} / \mathrm{g}$ food waste. 
Table 1-Characteristics of food waste used.

\begin{tabular}{ll}
\hline Parameters & Content $(\mathbf{w} / \mathbf{w}, \boldsymbol{\%})$ \\
\hline $\mathrm{pH}$ & 4.46 \\
Total solid (TS) & $20.45 \pm 1.32$ \\
Volatile total solid (VTS) & $18.47 \pm 1.12$ \\
Ash & $2.11 \pm 0.27$ \\
Moisture & $79.56 \pm 2.24$ \\
Total sugars" (based on wet weight) & $14.13 \pm 1.65$ \\
Total sugars" (based on dry weight) & $63.87 \pm 2.03$ \\
Cellulose (based on dry weight) & $1.98 \pm 0.36$ \\
Protein (based on dry weight) & $21.34 \pm 1.88$ \\
Lipid (based on dry weight) & $12.42 \pm 1.03$ \\
\hline "Total sugars referred to starch sugars. &
\end{tabular}
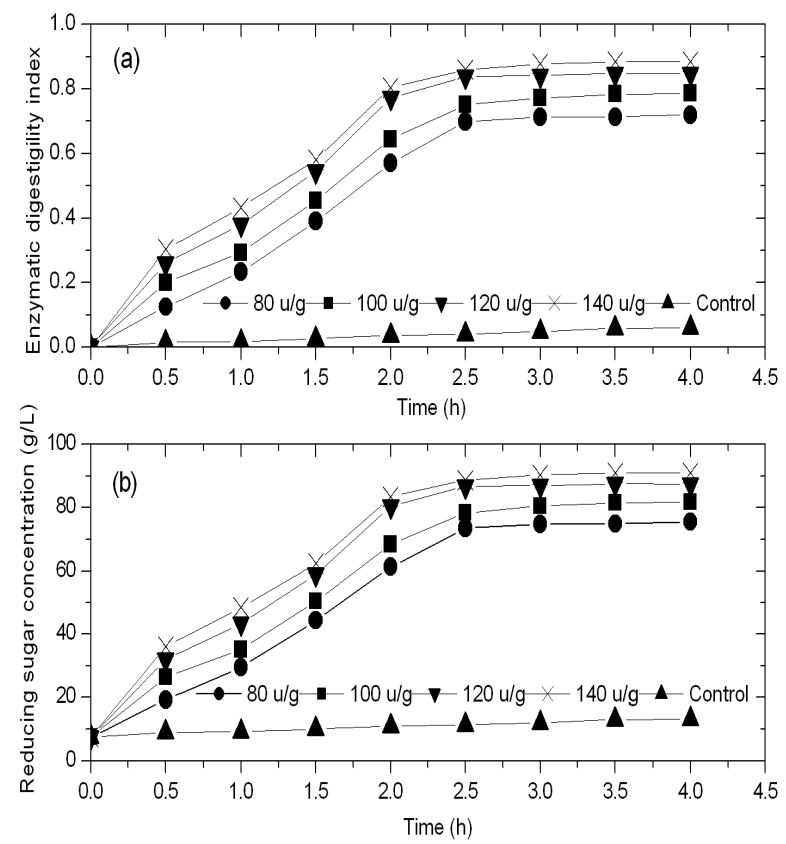

Figure 1 - Effect of varied concentration of glucoamylase on (a) enzymatic digestibility index and (b) reducing sugar concentration after 4 h enzymatic hydrolysis.

Effect of $\alpha$-amylase concentration on the enzymatic hydrolysis of food waste

In order to enhance the enzymatic saccharification of food waste, different dosages (presented as $\mathrm{u} / \mathrm{g}$ food waste) of $\alpha$-amylase were added to the pretreated food waste with constant glucoamylase of $120 \mathrm{u} / \mathrm{g}$ food waste for each treatment. It was found that for each enzyme dosage, enzymatic digestibility index and reducing sugar concentration increased sharply for the first $2.5 \mathrm{~h}$, and then more slowly from 2.5 to $4 \mathrm{~h}$ (Fig. 2). The optimal enzyme dosage was identified as $10 \mathrm{u} / \mathrm{g}$ food waste and further increase in enzyme dosage did not produce a corresponding increase in the hydrolysis yield.
Effect of temperature on the enzymatic hydrolysis of food waste

The hydrolysis of pretreated food waste was carried out at temperature ranging from 50 to $65^{\circ} \mathrm{C}$ (Fig. 3). The initial enzymatic digestibility increased with enhancing temperature, and maximum enzymatic digestibility was observed at $55^{\circ} \mathrm{C}$. Then enzymatic digestibility decreased when temperatures exceeded $55^{\circ} \mathrm{C}$. This result may be attributed to the thermal inactivation of glucoamylase or fungal $\alpha$-amylase. Therefore, the temperature of $55^{\circ} \mathrm{C}$ was found to be optimum for enzymatic hydrolysis of food waste. 

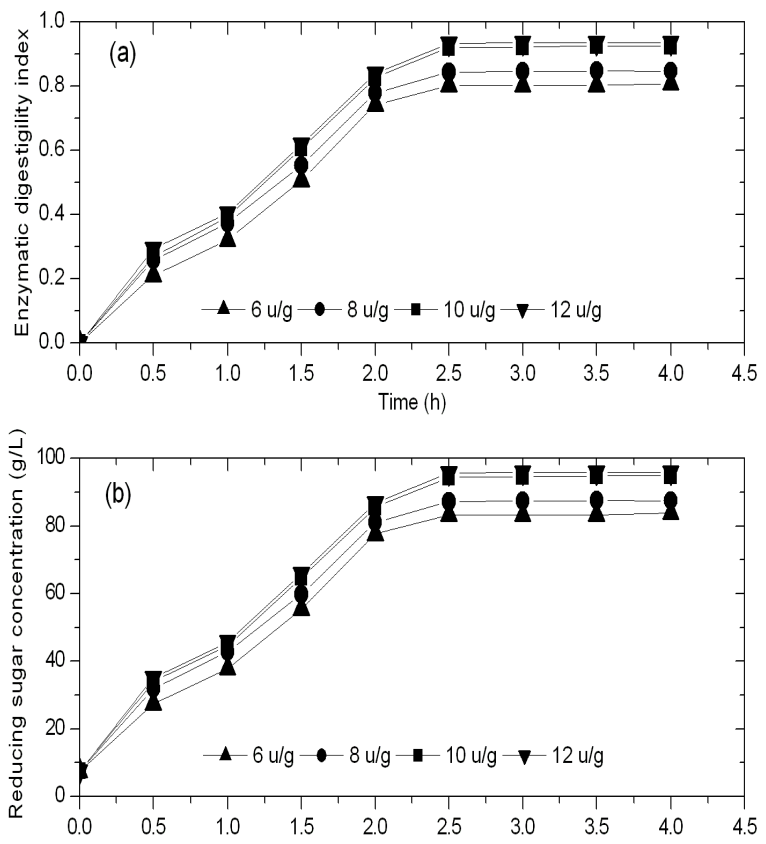

Figure 2 - Effect of varied concentration of $\alpha$-amylase on (a) enzymatic digestibility index and (b) reducing sugar concentration after $4 \mathrm{~h}$ enzymatic hydrolysis.

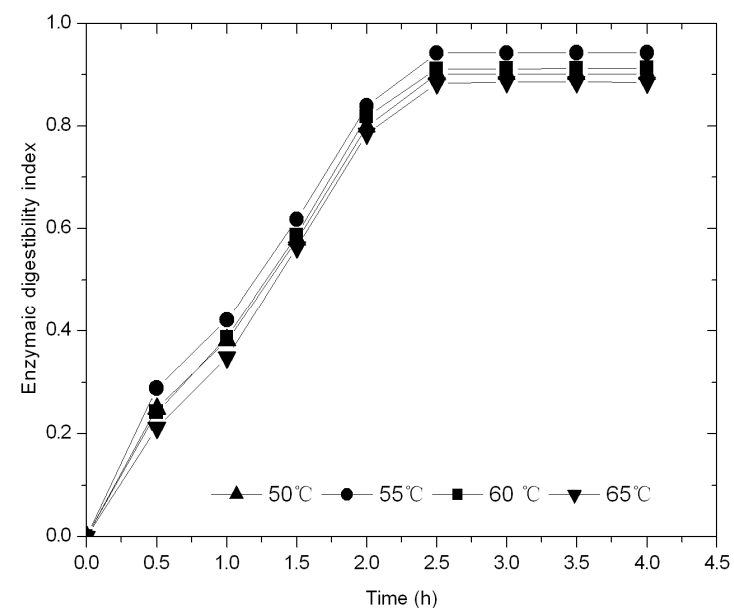

Figure 3 - Effect of temperature on enzymatic digestibility index after 4 h enzymatic hydrolysis.

Effect of $\mathrm{pH}$ on the enzymatic hydrolysis of food waste

The efficiency of fermentation process depends on the glucose concentration produced by saccharification process. According to the manufacturer's data sheet, glucoamylase and fungal $\alpha$-amylase were originally used for the saccharification of starch with the optimum $\mathrm{pH}$ of 4.0-4.5 and 4.0-6.5, respectively. However, as food waste is a complex mixture containing sugar, starch, cellulose, protein, fat, and mineral salts, it was expected that the optimum saccharification $\mathrm{pH}$ might be changed. Therefore, the effect of $\mathrm{pH}$ on the hydrolysis of food waste had been investigated in the $\mathrm{pH}$ range of 6.5 to 8.5 with other parameters fixed. Figure 4 shows maximum enzymatic digestibility index of 0.96 was achieved at $\mathrm{pH} 4.5$ (As expected). 


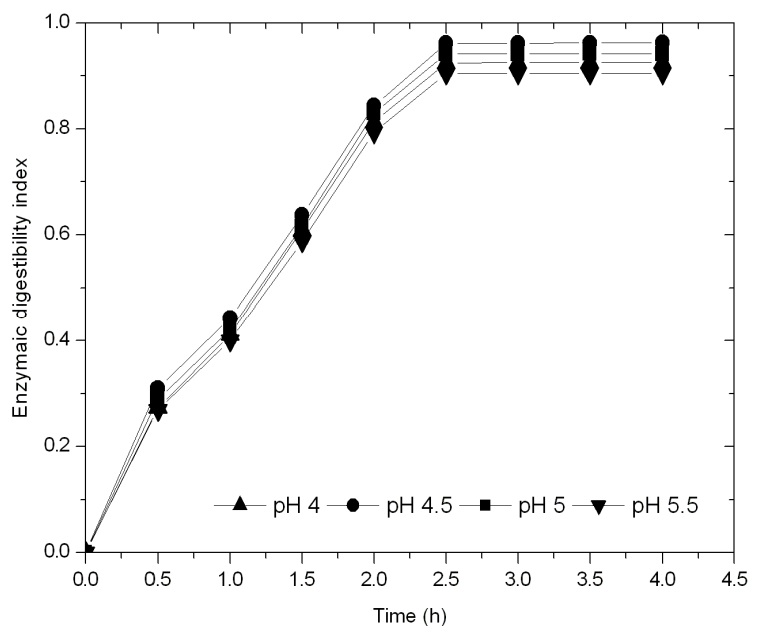

Figure 4 - Effect of pH on enzymatic digestibility index after 4 h enzymatic hydrolysis.

Effect of solid-liquid ratio on the enzymatic hydrolysis of food waste

Figure 5a shows that solid-liquid ratio has significant effect on both enzymatic digestibility and reducing sugar concentration. There is over $17 \%$ drop of enzymatic digestibility with the increase of solid-liquid ratio from 1: 1.25 to $1: 0.5$. An increase in the solid-liquid ratio from 1: 1.25 to 1: 0.75 only resulted in relatively small decrease of starch conversion. However, the reducing sugar concentration significantly increased from 68.89 to $117.72 \mathrm{~g} / \mathrm{L}$ after $2.5 \mathrm{~h}$ (Fig. 5b). A larger reduction in the starch conversion of approximately $20.27 \%$ was observed between solid-liquid ratio of 1: 0.5 and 1: 0.75 in the enzymatic hydrolysis step after 2 h. The similar effect was observed when using higher cellulase concentration up to $30 \mathrm{FPU} / \mathrm{g}$ cellulose to hydrolyze dilute acid pretreated saline crops and was more pronounced for long reaction times (48 $\mathrm{h}$ and longer) (Zheng et al. 2009). High solid-liquid ratio can result in mixing problems, which further hinder effective heat and mass transfers and limit diffusion of enzyme and end products. These problems were reflected by slow solid liquification and sampling difficulties. To solve the problems of high solid-liquid ratio during enzymatic hydrolysis, Manonmani and Sreekantiah (1987) tried to use extremely high enzyme concentration of approximately 100 FPU/g cellulose to obtain maximum cellulose conversion under the highest solid loading of $8 \%$. However, high enzyme concentration is not an economically practical solution to obtain both high cellulose conversion and glucose concentration. Improving mixing system of reactors and/or operation methods of enzymatic hydrolysis (e.g. using fed-batch to replace batch) could be effective solutions. In this study, the solid-liquid ratio 1: 0.75 was chose to be optimum considering the relative high enzymatic digestibility index and the reducing sugar concentration.

\section{Fed batch enzymatic hydrolysis}

An efficient recovery of ethanol seems to require a concentration higher than $40 \mathrm{~g} / \mathrm{L}$ (Phillips and Humphrey 1983), which in turn the process requires a starting concentrations of reducing sugars at least higher than $80 \mathrm{~g} / \mathrm{L}$. Raising the solid-liquid ratio in batch hydrolysis helps to obtain higher reducing sugar concentration and further to produce high concentration ethanol during fermentation process, which may substantially decrease the distillation cost for ethanol recovery. However, too high a solid-liquid ratio would cause mixing and heat transfers difficult so that the efficiency of enzymatic hydrolysis was low resulting in low enzymatic digestibility index and reducing suagr concentration. Applying fed-batch enzymatic hydrolysis will be a solution to these problems.

During the time course of fed batch enzymatic hydrolysis, the saccharification continued till $4 \mathrm{~h}$ and remained constant on prolonged incubation (Fig. 6). The maximum amount of reducing sugar (194.43 g/L) was released after $4 \mathrm{~h}$ of incubation with a enzymatic digestibility index 0.93 . It had over $22 \%$ higher enzymatic digestibility and more than $6 \%$ higher reducing sugar concentration than the batch process during hydrolysis of high solidliquid ratio of 1: $0.5(\mathrm{w} / \mathrm{w})$. Our results are also in 
accordance with the earlier work of Chen et al., where in the enzymatic saccharification of corncob high hydrolysis yield and reducing sugar concentration was achieved through fed batch process (Chen et al. 2007). In fed batch process, solid was added after the previous solid was completed or partially liquefied, which improved the mass and heat transfer significantly and generated high enzymatic digestibility and reducing sugar concentration.
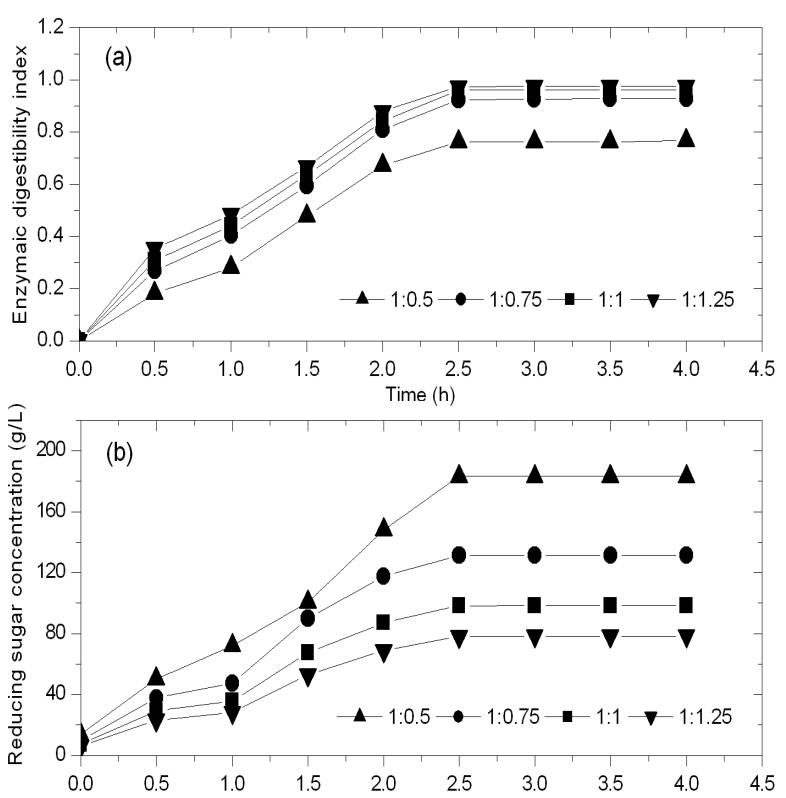

Figure 5 - Effect of solid-liquid ratio on (a) enzymatic digestibility index and (b) reducing sugar concentration after $4 \mathrm{~h}$ of enzymatic hydrolysis.

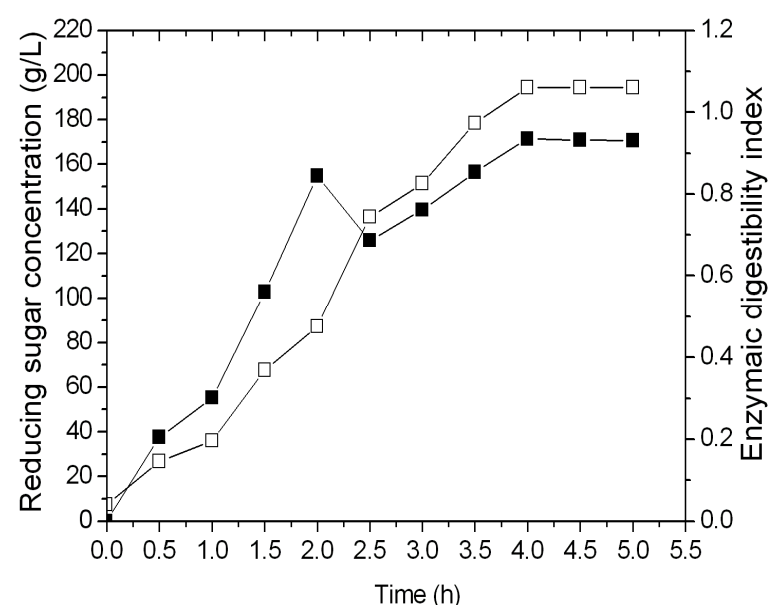

Figure 6 - Effect of fed batch method on enzymatic digestibility index and reducing sugar concentration.

\section{Fermentation}

The fermentation of batch enzymatic hydrolysate $(131.41 \mathrm{~g} / \mathrm{L}$ reducing sugars) produced $62.93 \mathrm{~g} / \mathrm{L}$ ethanol with yield and volumetric rate of ethanol production of 0.48 and $1.31 \mathrm{~g} / \mathrm{L} / \mathrm{h}$, respectively, after $48 \mathrm{~h}$ of incubation (Table 2). While, the fed batch enzymatic hydrolysate containing 194.43 g/L sugars, when fermented with Sacch. cerevisiae 
H058, produced $90.72 \mathrm{~g} / \mathrm{L}$ ethanol with yield of $0.47 \mathrm{~g} / \mathrm{g}$ and volumetric rate of ethanol production $(1.89 \mathrm{~g} / \mathrm{L} / \mathrm{h})$, after $48 \mathrm{~h}$ of incubation (Table 2). Theoretical yield of ethanol could reach as high as
0.511. Result of this study reached nearly $92 \%$ of the theoretical yield, considering the complex component of food waste, the result could be regarded as ideal.

Table 2 - Ethanol production profile from batch and fed batch enzymatic hydrolysate of food waste by Sacch.cerevisiae $\mathrm{H} 058$ at $30^{\circ} \mathrm{C}$, and $100 \mathrm{rpm}$.

\begin{tabular}{|c|c|c|c|c|c|c|c|c|}
\hline \multirow[b]{2}{*}{$\begin{array}{l}\text { Time } \\
\text { (h) }\end{array}$} & \multicolumn{4}{|c|}{ Batch enzymatic hydrolysate } & \multicolumn{4}{|c|}{ Fed batch enzymatic hydrolysate } \\
\hline & $\begin{array}{c}\text { Reducing } \\
\text { sugar }(\mathrm{g} / \mathrm{L})\end{array}$ & $\begin{array}{c}\text { Ethanol } \\
\text { (g/L) }\end{array}$ & $\begin{array}{c}\text { Ethanol } \\
\text { yield }(\mathrm{g} / \mathrm{g})\end{array}$ & $\begin{array}{c}\text { Volumetric rate } \\
\text { of ethanol } \\
\text { production }(\mathrm{g} / \mathrm{L} / \mathrm{h})\end{array}$ & $\begin{array}{c}\text { Reducing } \\
\text { sugar }(\mathrm{g} / \mathbf{L})\end{array}$ & $\begin{array}{c}\text { Ethanol } \\
\text { (g/L) }\end{array}$ & $\begin{array}{c}\text { Ethanol } \\
\text { yield (g/g) }\end{array}$ & $\begin{array}{c}\text { Volumetric rate } \\
\text { of ethanol } \\
\text { production }(\mathrm{g} / \mathrm{L} / \mathrm{h})\end{array}$ \\
\hline 0 & 131.41 & 0.00 & 0.00 & 0.00 & 194.43 & 0.00 & 0.00 & 0.00 \\
\hline 12 & 65.23 & 32.66 & 0.49 & 2.72 & 124.14 & 34.44 & 0.49 & 2.87 \\
\hline 24 & 31.56 & 46.93 & 0.47 & 1.96 & 40.32 & 73.97 & 0.48 & 3.08 \\
\hline 36 & 7.86 & 59.72 & 0.48 & 1.66 & 9.92 & 86.71 & 0.47 & 2.41 \\
\hline 48 & 1.12 & 62.93 & 0.48 & 1.31 & 1.34 & 90.72 & 0.47 & 1.89 \\
\hline 60 & 1.05 & 62.89 & 0.48 & 1.05 & 1.12 & 90.06 & 0.47 & 1.50 \\
\hline
\end{tabular}

\section{ACKNOWLEDGMENTS}

The present research was financially supported by The Chinese National Science and Technology Pillar Program in the Eleventh Five- year Plan Period(Grant No. 2007BAD89B10-5(5)).

\section{REFERENCES}

APHA (American Public Health Association); American Water Works Association and Water Environment Federation. Standard Methods for the Examination of Water and Wastewater, 19th ed. Washington DC: APHA; 1995.

Ballesteros M, Oliva JM, Manzanares P, Negro MJ and Ballesteros I. Ethanol production from paper materials using a simultaneous saccharification and fermentation system in a fed-batch basis. World $J$ Microb Biot. 2009; 18: 559-61.

Chen M, Xia LM. and Xue P.J. Enzymatic hydrolysis of corncob and ethanol production from cellulosic hydrolysate. Int Biodeter Biodegr. 2007; 59: 85-89.

Chinese National Standard GB/T 5009.4; 2003. Inspection of Grain and Oilseeds: Methods for Determination of Ash in Foods. Standards Press of China, Beijing, China.

Chinese National Standard GB/T 5009.10; 2003. Determination of crude fiber in vegetable foods. Standards Press of China, Beijing, China.

Cho JK, Park SC, Chang HN. Biochemical methane potential and solid state anaerobic digestion of Korean food wastes. Biores Technol. 1995; 52: 245253.
Choi DW, Lee WG, Lim SJ, Kim BJ, Chang HN and Chang ST. Simulation on Long-term Operation of an Anaerobic Bioreactor for Korean Food Wastes. Biotechnol. Bioproc. E. 2003; 8: 23-31.

Kuhad RC, Mehta G, Gupta R, Sharma KK, Fed batch enzymatic saccharification of newspaper cellulosics improves the sugar content in the hydrolysates and eventually the ethanol fermentation by Saccharomyces cerevisiae. Biomass Bioenerg. 2010; 1: 1-6.

Manonmani HK and Sreekantiah KR. Saccharification of sugar-cane bagasse with enzymes from Aspergillus ustus and Trichoderma viride. Enzyme Microb Technol. 1987; 9: 484-488.

Moon HC, Song S, Kim JC, Shirai Y, Lee DH, Kim JK, et al. Enzymatic hydrolysis of food waste and ethanol fermentation. Int J Energy Res. 2009; 33: 164-172.

Miller GL. Use of dinitrosalicylic acid reagent for determination of reducing sugar. Anal Chem. 1959; 31: 426-428.

Nielsen SS. Food analysis. 1th ed. China Light Industry Press, Beijing, 2002.

Rudolf A, Alkasrawi M, Zacchi G, Liden G. A comparison between batch and fed-batch simultaneous saccharification and fermentation of steam pretreated spruce. Enzyme Microb Technol. 2005; 37: 195-204.

Sakai K, Murata Y, Yamazumi H, Tau Y, Mori M, Moriguchi M, Shirai Y. Selective proliferation of lactic acid bacteria and accumulation of lactic acid during open fermentation of kitchen refuse with intermittent $\mathrm{pH}$ adjustment, Food Sci Technol Res. 2000; 6:140-145. 
Shin HS, Youn JH, Kim SH. Hydrogen production from food waste in anaerobic mesophilic and thermophilic acidogenesis. Int J Hydrogen Energ. 2004; 29: 13551363.

Somogyi M. Notes on sugar determination. J Biol Chem. 1952; 195: 19-23.

Tang YQ, Koike Y, Liu K, An MZ, Morimura SGR, $\mathrm{Wu}$ XL, Kid KJ. Ethanol production from kitchen waste using the flocculating yeast Saccharomyces cerevisiae strain KF-7. Biomass Bioenerg. 2008; 32: 1037-1045.

Wang Q, Wang X, Wang X, Ma H, Ren N. Bioconversion of kitchen garbage to lactic acid by two wild strains of Lactobacillus species. J Environ Sci Heal A. 2005; 40:1951-1962.
Yu J1, Zhang X, Tan TW. Optimization of media conditions for the production of ethanol from sweet sorghum juice by immobilized Saccharomyces cerevisiae. Biomass Bioenerg. 2009; 33: 521-526.

Zheng Y, Pan ZG, Zhang RH, Wang DH. Enzymatic saccharification of dilute acid pretreated saline crops for fermentable sugar production. Appl Energ. 2009; 86: $2459-2465$.

Received: November 06, 2010; Revised: January 20, 2011; Accepted: December 01, 2011. 